\title{
Improving Student Learning Outcomes With a Staffing Administration Module Based Guided Inquiry In Basic Competencies Suggested Leave Regulations
}

\author{
Dwi Novita Sari \\ I Nyoman Suputra \\ Education Administration Offices State University of Malang \\ Amin Chasanah \\ SMK Negeri 1 Malang \\ Email: dwinovita880@gmail.com
}

\begin{abstract}
The purpose of this study is to (1) produce personnel administration learning module Guided Inquiry-based for XI graders of Vocational School, particularly for office administration expertise program based on basic competence point 3.6 (proposing leave regulation) and 4.6 (reciting leave regulation), (2) validate the product through the validation test, (3) and find out the different learning outcome for those who used and did not used this product. there are different learning outcomes from those who belong to the control and experimental class namely 10,81 (control class average score $=82,58$ and experimental class average score $=93,39$ ).

Keywords: Learning Module, Personel Administration, Guided Inquiry, Learning Outcome.
\end{abstract}

Education is all effort and effort to make society can develop student potency to become better. In the Law of the Republic of Indonesia Number 20 Year 2003 on the National Education System, states that the purpose of education is to develop the potential of students to become human beings who believe and piety to God Almighty, have a noble character, healthy, knowledgeable, capable, creative, independent, and be a democratic and responsible citizen.

One of the efforts in achieving these goals is to implement a good curriculum that is able to print the nation's generation in order to compete with the international world. The improvement and refinement of the curriculum continue to be undertaken by the government. The effort was made to fix the deficiencies in the previous education system. The government has made improvements to the curriculum of KTSP 2006 to the curriculum of 2013. The 2013 curriculum aims to prepare the generation of the Indonesian nation with a system so that students are more active in teaching and learning activities. The objective of the curriculum according to Hamalik (2013: 86) is to provide the possibility of developing into a fully moral, moral, noble and strong character of diverse beliefs, which have a healthy and strong physical.

Many factors or strategies that can be used in improving the quality of education is improving the quality of learning. Improving the quality of learning can be done from various aspects of learning variables. Learning variables that are directly related to the quality of learning are the availability of qualified textbooks (Tarasov, 2015; Gurkaynak, 2015; Lee \& Zuilkowski, 2015; Wena, 2015).

Teachers in implementing the learning process is expected to use effective and efficient learning strategies. The success of teachers to apply a learning strategy depends on the ability of teachers to analyze existing learning conditions, such as learning objectives, student characteristics, learning resource constraints, 
and characteristics of the field of study (Wena, 2014: 14). The teaching and learning strategy according to Hasibuan \& Mudjiono (2012: 3) is a general pattern of teacher-student actions in the realization of teaching and learning activities. For teachers, strategies can be used as a systematic reference for action in implementing the learning process. One of them is by using guided inquiry learning strategy. The term "inquiry" comes from English, meaning inquiry which means question or inquiry (Mills et al., 2011; Gillies et al., 2012; Sanjaya (in Suyadi, 2013).

SMK Negeri 1 Malang is one of the country's favourite vocational high schools located at Jalan Sonokembang, Janti, Malang. There are 7 majors in SMK Negeri 1 Malang, one of which is the Office Administration. So far SMK Negeri 1 Malang has implemented the 2013 curriculum as a reference in the learning process. One of the learning subjects in the Office Administration skill program is the Civil Service Administration. During the learning process, teachers use a variety of references, both from the internet and other referral sources. There are no other modules or references that use the 2013 curriculum in the subjects of Civil Service Administration.

Based on the description above, then in this study selected the title "Development of Student Administration Based Training Module Guided Inquiry To Improve Student Learning Outcomes In Basic Competence Rule Leave Regard (Study In Class XI Program Administration Skills In SMK Negeri 1 Malang)".

\section{METHOD}

This research uses Research and Development (R \& D) method by Borg and Gall (in Sugiyono, 2014: 298). the development model described by Borg and Gall (in Sugiyono, 2014: 298) was modified and adapted to the needs of the study. Here's an image of the modified development model stage.

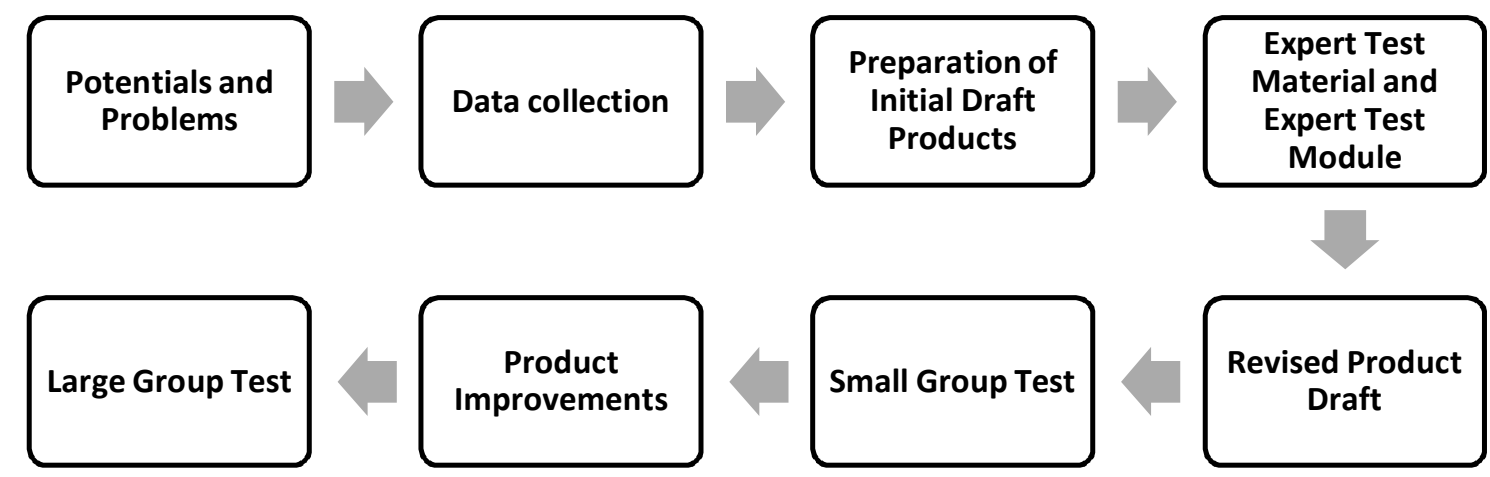

This research was conducted at SMK Negeri 1 Malang in class XI Office Administration Expertise Program. Subjects in this study that is, subject matter experts, subject module experts, and test subjects small groups and large groups. Determining the subjects of the trial need a certain criterion that becomes the reference in determining the subject of the trial. The subject of the materials expert and the module expert must have superior competence in their respective fields. For material experts will be conducted by teachers of Civil Service Administration class XI APK in SMK Negeri 1 Malang with the following criteria: a) understand the Curriculum 2013 well, b) has experience teaching personnel administration material for at least 1 year, c) has an academic degree with the minimum level of education S1, and d) understand the material Administration 
Personnel well. For module experts conducted by lecturers in the Education Studies Program Administration Office, majoring in Management, Faculty of Economics, State University of Malang. Module experts are selected according to the following criteria: a) understand the systematics of module writing well, b) understand the basics of visual design, c) have teaching experience in the field of teaching materials at least 1 year, and d) have an academic degree with minimum education level S2. The subjects of the small group test were conducted by the students of class XI APK 1 in SMK Negeri Malang, amounting to 6 students. While large group trials conducted by class XI APK 2, amounting to 31 students and class XI APK 4, amounting to 32 students.

The instruments of data collection in the development of this module are questionnaires, tests and interviews. The questionnaire consists of 3 aspects: 1 ) Questionnaire Expert Module, which is a questionnaire that contains an assessment of the content feasibility aspect, feasibility of presentation, feasibility of language and feasibility, 2) Questionnaire Material Expert, which questionnaire contains an assessment of the content feasibility aspects, the feasibility of presentation, the feasibility of language and feasibility of language, 3) student questionnaire, which is a questionnaire that contains an assessment of the content feasibility aspects, the feasibility of presentation, feasibility and language feasibility active. Furthermore the question of evaluation is used to know the students' understanding of the material that has been used in the module. The limitation of students is considered to master the module is in accordance with the Minimum Criteria of Completeness (KKM) determined is 75.00. Last interview, in this research, is done to subject teacher of Personnel Administration. It is used to search data supporting information in research.

Data analysis technique in this research is qualitative technique and quantitative technique. To analyze verbal data both verbal data were written and oral verbal data used qualitative data analysis techniques, while for numerical data both data obtained from the questionnaire and the value of student learning outcomes by using quantitative data analysis techniques. quantitative data analysis in this research is data analysis of validation and analysis of learning result. Validation data analysis is used to measure the feasibility and attractiveness of Learning Guided Personnel Administration of Guided Inquiry module obtained from questionnaires that have been filled by material experts, module experts, and students who are the subject of the small group test. Validation results are then analyzed by researchers by using the formula below:

$$
\text { Percentage }=\frac{\Sigma \text { Scores obtained from research }}{\Sigma \text { Ideal score in one item }} \times 100 \%
$$

To find out the conclusions of the results of the percentage analysis, the level of validity is developed. Table 1 below shows the classification of levels of validity criteria.

Table 1 Validity Criteria for Validation Data Validation

\begin{tabular}{cc}
\hline Percentage & Description \\
\hline $85 \%-100 \%$ & Very Valid \\
$70 \%-84 \%$ & Valid \\
$55 \%-69 \%$ & Less Valid \\
$<55 \%$ & Invalid \\
\hline
\end{tabular}

Source: Data processed from Sugiyono, 2014:125-136 
Based on Table 1, if the obtained validation results reach $\geq 70 \%$, then the module can be said to be worthy as a teaching material. Whereas if the validation results $\leq 70 \%$, then the module is not yet feasible to use and should be revised. Analysis of learning outcomes done by looking at the completeness of classical learning, namely the percentage of the number of students in a class whose learning achievement $\geq$ Minimum Exhaustiveness Criteria (KKM) used in SMK Negeri 1 Malang. KKM subjects Administration staffing class XI ADP is 75. Classical provisions in research and development are if the value of post-test> KKM then effective and vice versa, if the value of post-test <KKM then not effective. To calculate the mastery of the class can use the following formula.

Explanation

$$
K K=\frac{\sum X}{\sum X 1} x 100 \%
$$

$\mathrm{KK}=$ Grade Completion

$\sum \mathrm{X} \quad=$ Number of students earning $\geq$ KKM score

$\sum \mathrm{X} 1=$ Number of students taking the test

$100 \%=$ Constants

\section{RESULTS \& DISCUSSION}

The product of the development results in this research is in the form of printed teaching materials, namely the Civil Service Administration-based instructional module with the subject matter of the Leave Regulation which is completed with teacher handbook containing the answer key and the scoring rubric for all questions contained in the student module. The steps of implementing the inquiry learning strategy are used as a step in using the module. The steps of implementing the inquiry learning strategy used as the stage of using the development result module are 1) orientation, 2) formulating the problem, 3) formulating the hypothesis, 4) collecting the data, 5) testing the hypothesis, 6) formulating the conclusion. This module was developed to support the teaching and learning process in the classroom and improve the learning outcomes of the students of class XI of the Office Administration Program in SMK Negeri 1 Malang based on the curriculum 2013. Through the inquiry learning strategy students can be involved in the process of understanding the problem, formulating hypotheses, collecting data and analyzing data, as well as make conclusions about the problems encountered, so that learning is more meaningful.

The results of module validation questionnaires for students and teacher handbook by material experts can be seen in Table 2 and Table 3 below.

Table 2 Quantitative Data Result of Expert Material Validation for Student Module

\begin{tabular}{|c|c|c|c|c|c|}
\hline \multirow[t]{2}{*}{ No } & \multirow[t]{2}{*}{ Explanation } & \multicolumn{2}{|c|}{ Score } & \multirow{2}{*}{$\begin{array}{c}\text { Percentage } \\
\% \% \\
\end{array}$} & \multirow[t]{2}{*}{ Criteria } \\
\hline & & $\sum X$ & $\sum \mathbf{X i}$ & & \\
\hline 1 & Feasibility of Content & 32 & 36 & 88,89 & Very Valid \\
\hline 2 & $\begin{array}{l}\text { Feasibility of } \\
\text { Presentation }\end{array}$ & 42 & 48 & 87,5 & Very Valid \\
\hline 3 & Channel Feasibility & 68 & 80 & 85 & Very Valid \\
\hline 4 & Language Feasibility & 42 & 52 & 80,76 & Valid \\
\hline Tot & Earnings & 184 & 216 & 85,18 & Very Valid \\
\hline
\end{tabular}


Description:

$\Sigma \mathrm{X}=$ Total scores obtained

$\Sigma \mathrm{Xi}=$ Maximum score

Based on the results of questionnaire validation data of material experts presented in Table 2 obtained a total validation percentage of $85.18 \%$ where the number indicates the Guided Inquiry-based Personnel Administration module has a criterion very valid/fit to use.

Table 3 Quantitative Data Expert Material Validation Results For Master Handbook

\begin{tabular}{|c|c|c|c|c|c|}
\hline \multirow[t]{2}{*}{ No } & \multirow[t]{2}{*}{ Keterangan } & \multicolumn{2}{|c|}{ Score } & \multirow{2}{*}{$\begin{array}{c}\text { Persentage } \\
\%\end{array}$} & \multirow[t]{2}{*}{ Criteria } \\
\hline & & $\sum \mathbf{X}$ & $\sum \mathbf{X i}$ & & \\
\hline 1 & Feasibility of Content & 11 & 12 & 91,67 & Very Valid \\
\hline 2 & $\begin{array}{l}\text { Feasibility of } \\
\text { Presentation }\end{array}$ & 24 & 28 & 85,71 & Very Valid \\
\hline 3 & Channel Feasibility & 53 & 64 & 82,81 & Valid \\
\hline 4 & Language Feasibility & 10 & 12 & 83,33 & Valid \\
\hline \multicolumn{2}{|c|}{ Total Earnings } & 98 & 116 & 84,48 & Valid \\
\hline
\end{tabular}

Source: Quantitative data of expert material validation results for teacher handbooks processed by researchers, 2017

Description:

$\Sigma \mathrm{X}=$ Total scores obtained

$\Sigma \mathrm{Xi}=$ Maximum score

Based on the results of questionnaire validation data of material experts presented in Table 3 obtained a total validation percentage of $84.48 \%$ which indicates that the Guided Inquiry-based Personnel Administration module has valid / proper-use criteria. The results of module validation questionnaires for students and teacher handbooks by module experts can be seen in Table 4 and Table 5 below.

Table 4 Quantitative Data Result of Module Expert Validation for Student Module

\begin{tabular}{|c|c|c|c|c|c|}
\hline \multirow[t]{2}{*}{ No } & \multirow[t]{2}{*}{ Describtion } & \multicolumn{2}{|c|}{ Score } & \multirow{2}{*}{$\begin{array}{c}\text { Persentage } \\
\%\end{array}$} & \multirow[t]{2}{*}{ Criteria } \\
\hline & & $\sum \mathbf{X}$ & $\sum \mathbf{X i}$ & & \\
\hline 1 & Feasibility of Content & 33 & 36 & 91,67 & Very Valid \\
\hline 2 & $\begin{array}{l}\text { Feasibility of } \\
\text { Presentation }\end{array}$ & 46 & 48 & 95,83 & Very Valid \\
\hline 3 & Channel Feasibility & 77 & 80 & 96,25 & Very Valid \\
\hline 4 & Language Feasibility & 50 & 52 & 96,15 & Very Valid \\
\hline \multicolumn{2}{|c|}{ Total Earnings } & 184 & 216 & 95,37 & Very Valid \\
\hline
\end{tabular}

Source: Quantitative data on module expert validation results for student modules processed by researchers, 2017

Description:

$\Sigma \mathrm{X}=$ Total scores obtained

$\Sigma \mathrm{Xi}=$ Maximum score

Based on the results of questionnaire validation data of module experts presented in Table 4 obtained a total validation percentage of $95.37 \%$ which 
indicates that the Guided Inquiry-based Personnel Administration module has very valid / proper-use criteria.

Table 5 Quantitative Data Expert Module Validation Results For Master Handbook

\begin{tabular}{|c|c|c|c|c|c|}
\hline \multirow[t]{2}{*}{ No } & \multirow[t]{2}{*}{ Description } & \multicolumn{2}{|c|}{ Score } & \multirow{2}{*}{$\begin{array}{c}\text { Percentagege } \\
\% \\
\end{array}$} & \multirow[t]{2}{*}{ Criteria } \\
\hline & & $\sum \mathrm{X}$ & $\sum X \mathbf{i}$ & & \\
\hline 1 & Feasibility of Content & 11 & 12 & 91,67 & Very Valid \\
\hline 2 & $\begin{array}{l}\text { Feasibility of } \\
\text { Presentation }\end{array}$ & 26 & 28 & 92,85 & Very Valid \\
\hline 3 & Channel Feasibility & 62 & 64 & 96,87 & Very Valid \\
\hline 4 & Language Feasibility & 10 & 12 & 83,33 & Valid \\
\hline \multicolumn{2}{|c|}{ Total Earnings } & 109 & 116 & 93,96 & Very Valid \\
\hline
\end{tabular}

Source: Quantitative data on module expert validation results for teacher handbooks processed by researchers, 2017

Description:

$\Sigma \mathrm{X}=$ Total scores obtained

$\Sigma \mathrm{Xi}=$ Maximum score

Based on the results of questionnaire validation data of module experts presented in Table 5 obtained a total validation percentage of $93.96 \%$ which indicates that the Guided Inquiry-based Personnel Administration module has very valid / proper-use criteria.

The results of module validation questionnaires for participants by small group test students can be seen in Table 6 below.

Table 6 Quantitative Data Result of Student Validation.

\begin{tabular}{llcccl}
\hline \multirow{2}{*}{ No. } & \multicolumn{1}{c}{ Validator } & \multicolumn{2}{c}{ Score } & Percentage & \multirow{2}{*}{ Criteria } \\
\cline { 3 - 5 } & & $\mathbf{\Sigma X}$ & $\mathbf{\Sigma X i}$ & $\mathbf{\%}$ & \\
\hline 1 & Student 1 (Anita) & 39 & 44 & 88,63 & Very Valid \\
\hline 2 & Student 2 (Agnes Praptaningrum) & 40 & 44 & 90,9 & Very Valid \\
\hline 3 & $\begin{array}{l}\text { Student 3 (Delliana Novelitha } \\
\text { Aviany) }\end{array}$ & 40 & 44 & 90,9 & Very Valid \\
\hline 4 & Student 4 (Aprilia Damaiyanti) & 42 & 44 & 95,45 & Very Valid \\
\hline 5 & Student 5 (Desy Mutiara Sary) & 42 & 44 & 95,45 & Very Valid \\
\hline 6 & Student 6 (Anita Rahayu Ningsih) & 41 & 44 & 93,18 & Very Valid \\
\hline Total Earnings & $\mathbf{2 4 4}$ & $\mathbf{2 6 4}$ & $\mathbf{9 2 , 4 2}$ & Very Valid \\
\hline
\end{tabular}

Source: Quantitative data of validation results by students processed by researchers, 2017

Description:

$\Sigma \mathrm{X}=$ Total scores obtained

$\Sigma \mathrm{Xi}=$ Maximum score

Based on the results of questionnaires validation test small group presented in Table 6 obtained a total validation percentage of $92.42 \%$ where the number indicates the Guided Inquiry-based Personnel Administration module has criteria very valid/fit to use.

Results of analysis of student learning outcomes in SMK Negeri 1 Malang is as follows. 
Table 7 Data on Student Results Class Control And Experimental Class

\begin{tabular}{lcc}
\hline & $\begin{array}{c}\text { Student Post Test Class } \\
\text { Rating Control }\end{array}$ & $\begin{array}{c}\text { Value of Post Test of Student of } \\
\text { Experiment Class }\end{array}$ \\
\hline Total Value of All Students & 2560 & 2895 \\
\hline Class Average Value & 82,58 & 93,39 \\
\hline $\begin{array}{l}\text { Number of Students } \\
\text { Completed }\end{array}$ & 29 & 31 \\
\hline $\begin{array}{l}\text { \% Number of Students } \\
\text { Completed }\end{array}$ & 93,55 & 100 \\
\hline $\begin{array}{l}\text { Number of Students Who } \\
\text { Present }\end{array}$ & 31 & 31 \\
\hline
\end{tabular}

Source: Student grade and experimental class study result data, 2017

Based on the data described in Table 7, it is known that the mean score of students' learning outcomes is 82.58 and the experimental class is 93.39 . So there is a difference between the control class and the experimental class of 10.81. In addition, from the data, there is a difference of percentage of class mastery between control class and experiment class that is equal to 3,33\%. Thus, it can be said that the Guided Inquiry-based Personnel Administration module is effectively used as teaching material in classroom learning activities and can improve student learning outcomes.

\section{Discussion}

The product of the development results in this research is in the form of printed teaching materials, namely the Civil Service Administration-based instructional module with the subject matter of the Leave Regulation which is completed with teacher handbook containing the answer key and the scoring rubric for all questions contained in the student module. The steps of implementing the inquiry learning strategy are used as a step in using the module. The steps of implementing the inquiry learning strategy used as the stage of using the development result module are 1) orientation, 2) formulating the problem, 3) formulating the hypothesis, 4) collecting the data, 5) testing the hypothesis, 6) formulating the conclusion.

The inquiry learning strategy is a series of instructional activities that emphasize critical and analytical thinking processes (Uzunoz \& Demirhan, 2017; Carter et al., 2017; Art-in, 2015; Majid, 2015). The advantage of inquiry learning strategy has the advantage that this strategy is a learning strategy that emphasizes the development of cognitive, affective and psychomotor aspects equally (Chang et al, 2017; Aldridge, 2017; Majid, 2015).

The first step in the guided inquiry is orientation, aiming to foster a responsive atmosphere or learning climate so that students are ready to carry out the learning process (Khedhaouria et al, 2017, Poondej \& Lerdpornkulrat, 2016: Koopman et al 2014, Albert \& Dahling, 2016 Majid, 2015).

The second step in the guided inquiry is to formulate the problem, is the step of involving the students on one issue that contains the puzzles presented is a problem that challenges the students to think solving the puzzle because the problem must be the answer so that students are encouraged to find the right answer ( $\mathrm{Wu}$ et al, 2016; Wahi \& Lovseth, 2015; Lyles, 2014; Chali et al. 2015: Majid, 2015). The third step in the guided inquiry is to formulate a hypothesis, the hypothesis being a temporary answer to a problem under study. As a temporary 
answer, the hypothesis needs to be verified (Huang et al 2014, Jahangiri \& Abilipour, 2014, Yu et al, 2016; Monks et al., 2014; Majid, 2015). The fourth step in the guided inquiry is collecting data, information needed to test the proposed hypothesis (Saarinen et al, 2017, Depoy \& Gitlin, 2016; Deufemia et al 2014; Majid 2015). The fifth step in the guided inquiry is to test the hypothesis, the process of determining the answer that is deemed to be accepted in accordance with the data or information obtained on the basis of data collection (Donnarumma et al. 2017; Zhou et al. 2017; Barsotti et al. 2016, Majid, 2015). The last step in the guided inquiry is to formulate a conclusion, a process of describing the findings obtained on the basis of hypothesis testing (Lucena-Molina, 2016; Tan, 2017; Majid, 2015).

The guided inquiry personnel-based personnel training module that has been developed by this researcher has been through validation step by material experts, module experts, and students. There are 4 aspects of assessment in developed modules, the first of which is the content feasibility aspect. To maximize the success of learning in learning activities, this module includes exercises to train students to think critically to solve problems (Ruggiero \& Green, 2017; Kashani-vahid et al 2017; Iglesias-sarmiento et al, 2017; Kim et al, 2016; Chow et al., 2016). Second, the aspect of the feasibility of presentation. Administration module based on guided inquiry based on systematic, demands and completeness of presentation. The three aspects of the feasibility of effectiveness, aspects of include (a) the size of teaching materials, (b) module cover skin design, (c) module contents design. In the manufacture of modules, researchers chose A4 paper 70 grams. The module cover is designed with an image representing the subject matter in the module. The cover (front and back) is designed with a blue background so that the appearance is not monotonous and the cover is more interesting. Fourth, the language feasibility aspect, The language used in this module is adjusted to the level of students' thinking ability. His choice of speech is scientific but not rigid.

\section{CONCLUSION \& SUGGESTIONS}

Based on the review of the revised development results, the following conclusions can be drawn: (1) the results of the development in this study are Student Administration-Based Administration Module Guided Inquiry for Vocational Secondary (SMK) students of XI Class Office Administration even semester, (2) based on result validation by material experts, module experts and small groups that test the feasibility of the content, presentation, language and kegrafikan states that this development result module is very valid/appropriate to be used as teaching material of regulation subject of Staffing Administration subject in SMK, (3) effectively used in learning activities for students of class XI SMK in terms of differences in student learning outcomes experimental class higher than the control class.

Based on the results of the trial, it is known that the results of this development have been valid and effective use as a teaching material in the process of learning Personnel Administration. The guidance of utilization of development result module is as follows: a) Guided Inquiry-based Personnel Administration module can be used as an additional source of learning in the process of teaching and learning activities in class, b) students are advised to use 
Guided Inquiry-based Personnel Administration Module for critical thinking ability and analytical students to the maximum. Students can practice understanding of the modules in the school with the guidance of teachers and at home independently.

\section{REFERENCES}

Albert, M.a \& Dahling J. J. 2016. Learning goal orientation and locus of control interact to predict academic self-concept and academic performance in college students. Personality and Individual Differences. 97 (1): 245-248. (Indonesian Origin).

Aldridge, M.D. 2017. Nursing students' perceptions of learning psychomotor skills: A Literature Review. Teaching and Learning in Nursing. 12 (1): 21-27. (Indonesian Origin).

Arifin, Z. 2013. Evaluation of Learning. Bandung: PT Remaja Rosdakarya. (Indonesian Origin).

Arikunto, S. 2010. Research Procedures A Practice Approach. Jakarta: Rineka Cipta. (Indonesian Origin).

Arikunto, S. 2012. Fundamentals of Educational Evaluation. Jakarta: PT Bumi Aksara. (Indonesian Origin).

Art-in, S. 2015. Current situation and need in learning management for developing the analytical thinking of teachers in the basic education of Thailand. Procedia - Social and Behavioral Sciences, 197 (1): 1494-1500. (Indonesian Origin).

Barsotti, F. 2016. Hypothesis testing for Markovian models with random time observations. Journal of Statistical Planning and Inference. 173 (1): 87-98. (Indonesian Origin).

Charter. A.G. 2017. Critical thinking skills in midwifery practice: Development of a selfassessment tool for students. Midwifery. 50 (1): 184-192. (Indonesian Origin).

Chali, Y. 2015. A reinforcement learning formulation to the complex question answering problem. Information processing \& Management. 51 (3): 252-272. (Indonesian Origin).

Chang, C. C. 2017. Is game-based learning better in flow experience and various types of the cognitive load than non-game-based learning? Perspective from multimedia and media richness. Computers in Human Behavior. 71 (1): 218-227. (Indonesian Origin).

Chow, P. K. Y. 2016. How practice makes perfect: the role of persistence, flexibility and learning in problem-solving efficiency. Animal Behavior. 112 (1): 273-283. (Indonesian Origin). 
Deufemia, V. 2014. A volunteered geographic information system for collecting and rating petroglyph data. Journal of Visual Languages \& Computing. 25 (6): 963-972. (Indonesian Origin).

Donnarumma, F. 2017. Action perception as hypothesis testing. Cortex. 89 (1): 45-60. (Indonesian Origin).

Gillies, R.M. 2012. The Effects of two strategic and meta-cognitive questioning approaches on children's explanatory behaviour, problem-solving, and learning during cooperative, inquiry-based science. International Journal of Educational Research. 53 (1): 93-106.

Gurkaynak, E. 2015. A Textbook Adaptation Using Data Gathered from a Multiple Intelligence Inventory. Procedia - Social and Behavioral Sciences, 199 (1): 285-292. (Indonesian Origin).

Hamalik, O. 2013. Learning and teaching process. Jakarta: PT Bumi Aksara. (Indonesian Origin).

Hasibuan, J.J \& Moedjjiono. 2012. Proses Belajar Mengajar. Bandung: PT Remaja Rosdakarya. (Indonesian Origin).

Hwang, P. 2014. Formulating appropriate statistical hypotheses for treatment comparison in clinical trial design and analysis. Contemporary Clinical Trials. 39 (2): 294-302. (Indonesian Origin).

Iglesias-Sarmiento, V. 2017. Mathematical learning disabilities and attention deficit and/or hyperactivity disorder: A study of the cognitive processes involved in arithmetic problem-solving. Reseach in Developmental Disabilities. 61 (1): 44-54. (Indonesian Origin).

Indriyanti, N.M. \& Endang, S. 2010. Pengembangan Modul (online), (http://staff.uns.ac.id), diakses tanggal 21 Oktober 2016. (Indonesian Origin).

Jahangiri, K \& Abilipour, I. 2014. Effect of collaboration and exercise type on incidental vocabulary learning: Evidence Against Involvement Load Hypothesis. Procedia Social and Behavioral Sciences. 98 (1): 704-712. (Indonesian Origin).

Kashani-Vahid, L. 2017. Can a creative interpersonal problem-solving program improve creative thinking in gifted elementary students. Thinking skills and creativity. 24 (1): 175-185. (Indonesian Origin).

Khedhaouria, A. 2017. Time pressure and team member creativity within R\&D projects: The role of learning orientation and knowledge sourcing. International Journal of Project Management. 35 (6): 942-954. (Indonesian Origin).

Kim, H. 2016. Effects of team-based learning on problem-solving, knowledge and clinical performance of Korean nursing students. Nurse Education Today. 28 (1): 115-118. (Indonesian Origin). 
Koopman, M. 2014. Students' goal orientations and learning strategies in a powerful learning environment: A case study. Studies in Educational Evaluation. 43 (1): 186196. (Indonesian Origin).

Kusumawardani, F.T. 2013. Pengembangan Modul Pembelajaran Mengidentifikasi Dokumen-dokumen kantor PadaMata Diklat Melakukan Prosedur Administrasi Untuk Siswa Kelas X Prodi Administrasi Perkantoran (online), http://ejournal.unesa.ac.id, diakses tanggal 24 Oktober 2016. (Indonesian Origin).

Lee, J \& Zuilkowski, S. S. 'Making do': Teachers coping strategies for dealing with textbook shortages in urban Zambia. Teaching and Teacher Education. 48 (1): 117128. (Indonesian Origin).

Lucena-Molina, J. 2016. Epistemology applied to conclusions of expert reports. Forensic Science International. 264 (1): 122-131. (Indonesian Origin).

Lyles, M. A. 2014. Organizational Learning, knowledge creation, problem formulation and innovation in messy problems. European Management Journal. 32 (1): 132-136. (Indonesian Origin).

Majid, A. 2015. Learning Strategy. Bandung: PT Remaja Rosdakarya. (Indonesian Origin).

Mawantia, T et al. 2013. The development of Guided Inquiry Modules on Highlights of Reduced Oxidation Reactions for Online X Class Vocational Students, http://jurnalonline.um.ac.id, accessed on 24 October 2016. (Indonesian Origin).

Mills, C.M. 2011. Determining who to ask, what is the development of inquiry in young children? Journal of Experimental Child Psychology. 110 (4): 539-560. (Indonesian Origin).

Monks, T. 2014. Learning from discrete-event simulation: Exploring the high involvement hypothesis. European Journal of Operational Reseach. 235 (1): 195205.

Poondej, C \& Lerdpornkulrat, T. 2016. The relationship between motivational goal orientations, perceptions of general education classroom learning environment, and deep approaches to learning. Kasetsart Journal of Social Sciences. 37 (2): 100-103. (Indonesian Origin).

Prastowo, A. 2011. Creative Guide for Creating Innovative Instructional Materials. Jogjakarta: DIVA Press. (Indonesian Origin).

Puti, S.J. 2013. Development of Script Based Guided Junior IPA Module To Improve Process Skills and Scientific Attitudes (online), http://journal.uny.ac.id, accessed on 24 October 2016. (Indonesian Origin). 
Ruggiero, D \& Green L. 2017. Problem-solving through digital game design: A quantitative content analysis. Computers in Human Behavior. 73 (1): 28-37. (Indonesian Origin).

Saarinen, N. 2017. Feasibility of terrestrial laser scanning for collecting stem volume information from single trees. ISPRS Journal of Photogrammetry and Remote Sensing. 123 (1): 140-158. (Indonesian Origin).

Sodikun, et al. 2015. Development of Inquiry-Based Modules Guided on Food Digestion System Material to Improve the Skills of the Science Process (online), http://jurnal.fkip.uns.ac.id, accessed on 24 October 2016. (Indonesian Origin).

Stupple, E. J. N. 2017. Development of the critical thinking toolkit (CnTT): A measure of student attitudes and beliefs about critical thinking. Thinking Skills and Creativity. 23 (1): 91-100. (Indonesian Origin).

Sugiyono. 2014. Qualitative Quantitative Research Methods and R \& D. Bandung: Alfabeta. (Indonesian Origin).

Suyadi. 2013. Character Education Learning Strategy. Bandung: PT Remaja Rosdakarya. (Indonesian Origin).

Tan. L. 2017. 16. Conclusions and further research. A Generalized Framework of Linear Multivariable Control. Pages 293-298. (Indonesian Origin).

Tarasov, D.A. 2015. Legibility Of Textbooks: A Literature Review. Procedia - Social and Behavioral Sciences, 174 (1): 1300-1308. (Indonesian Origin).

UU no. 20 Year 2003 on National Education System. Jakarta: Depdiknas. (Indonesian Origin).

Uzunoz, F.S \& Demirhan, G. 2017. The effect of creative drama on critical thinking in preservice physical education teachers. Thinking Skills and Creativity. 24 (1): 164174. (Indonesian Origin).

Wahl. P.E \& Lovseth S. W. 2015. Formulating the optimization problem when using sequential quadratic programming applied to a simple LNG process. Computer \& Chemical Engineering. 82 (1): 1-12. (Indonesian Origin).

Wena, M. 2014. Strategic Innovative Learning Strategy. Jakarta: PT Bumi Aksara. (Indonesian Origin).

$\mathrm{Wu}, \mathrm{W} .22016$. Including stakeholders input in formulating and solving real-world optimization problems: Generic framework and case study. Environmental Modeling \& Software. 79 (1): 197-213. (Indonesian Origin).

Yu, D. J. 2016. Learning for resilience-based management: Generating hypotheses from a behavioural study. Global Environmental Change. 37 (1): 69-78. (Indonesian Origin). 
Zhou, B. 2016. An electric vehicle dispatch module for demand-side energy participation. Applied Energy. 177 (1): 464-474. (Indonesian Origin).

Zhou, B. 2017. High-dimensional general linear hypothesis testing under heteroscedasticity. Journal of Statistical Planning and Inference. 188 (1): 36-54. (Indonesian Origin). 